\title{
Reintroduction of Bovine Herpes Virus Type 1 into Danish Cattle Herds During the Period 1991-1995: A review of the investigations in the infected herds
}

\author{
By B. Nylin ${ }^{1,2}$, K. G. Madsen ${ }^{3}$ and L. Rønsholt ${ }^{3}$ \\ ${ }^{1}$ Cattle Health Laboratory, Danısh Dairy Board, Brørup, and ${ }^{2}$ Department of Anımal Science and Anımal Health, \\ The Royal Veteriary and Agricultural University, Frederiksberg, and ${ }^{3}$ Danısh Veterınary Institute for Virus \\ Research, Lindholm, Denmark.
}

\begin{abstract}
Nylin B, Madsen KG, Rønsholt L: Reintroduction of bovine herpes virus type 1 into Danish cattle herds during the period 1991-1995. A review of the investigations in the infected herds. Acta vet. scand. 1998, 39, 401-413. - In Denmark a programme for the systematic eradication of bovine herpes virus 1 (BHV-1) was completed during the years 1984 to 1991, but outbreaks due to new introductions of BHV-1 were seen. Between January 1991 and May 1994, 22 herds became infected with BHV-1, all located closely to the German border. In 1995, 61 herds were detected BHV-1 antibody positive, but they were situated in many different parts of Denmark.

In order to find the source of infection owners of infected herds were interviewed, and restriction fragment pattern analysis (RFP-analysis ) was performed on virus isolates from the herds with clinical outbreaks. Isolates from clinical outbreaks up to 1995 were 1dentıfied as a Cooper-like strain, while 2 of those in 1995 had characteristics of a "new" strain, which had never before been identıfied in Denmark or elsewhere in Europe. In the described situation different transmission routes for virus seemed possible One being a sporadic introduction of virus due to accidental contact with infected cattle near the German border or maybe due to an airborne transmission of virus over longer distance. The other, presumably a result of import of an infected animal despite the national regulations. The latter, due to an extensive trade pattern, resulted in the introduction of infected cattle into 51 BHV-1 seronegative cattle herds.
\end{abstract}

BHV-1; IBR; RFP-analysis; epidemiology; transmission; Denmark.

\section{Introduction}

A programme for the systematic eradication of bovine herpes virus 1 (BHV-1), the causative agent for infectious bovine rhinotracheitis (IBR) and pustular vulvo-vaginitis (IPV), was carried out in Denmark from 1984 to 1991. In the beginning of 1991 few seropositive herds were still present, but the infection was under control and no acute outbreaks were recorded in these herds. From March 1991 the surveillance programme was in progress, and Denmark ob- tained a European Union official BHV-1 free status in December 1992.

The eradication programme was based on blood testing of all herds and slaughtering of the BHV-1 seropositive reactors. The use of BHV1 vaccines was prohibited.

Despite the effectıve eradication programme, new seropositive herds were recorded in the period 1991 to 1995 .

The aim of this report is to describe the labora- 
tory and epidemiological findings related to the infected herds during the period 1991-1995 based on data collected in collaboration with the Committee for Control of Infectious Cattle Diseases, the Danish Veterinary Institute for Virus Research and the State Veterinary Services. On the basis of these results, the route of introduction of BHV-1 into the Danish cattle population is discussed.

\section{Materials and methods}

The Danish surveillance programme from 1991-1995

During the eradication campaign and in the following surveillance program, the BHV-1 status in dairy herds was monitored by testing bulk tank milk samples 4 times a year, and suspected positive reactions were followed up by serological testing of all cattle in the herd. Monthly testing of bulk milk samples from herds in southern Jutland was carried out from October to May. In addition, blood samples were taken at slaughter from one out of every 6 cattle older than 8 months and tested for BHV-1 antibodies. As a result of the detection of several BHV-1 infected herds in 1995, a special survey for BHV-1 antibodies in cattle from all non-dairy herds was established by testing individual serum samples from $10 \%$ of the cattle in each herd.

\section{Data collected from suspected positive herds}

In accordance with national regulations all cattle herds suspected of being positive by the surveillance system, either because of a positive reaction in a bulk tank milk sample or a positive reaction in a blood sample taken at slaughter, were blood tested to confirm or reject the suspicion and to identify the number of infected animals. Material from herds showing typical clinical signs were sampled by nasal swabs and analysed for the presence of BHV-1 virus.

\section{Interview data from infected herds}

In an attempt to reduce further spread of infected animals and to find the route of virus introduction, the owners in confirmed BHV-1 positive herds were interviewed by the state veterinary officers about movement of cattle to and from the herd. Purchased test-positive cattle were traced to the herd of origin, and such herds were blood tested. In herds receiving cattle from test-positive herds, purchased cattle were blood tested, and in case of a BHV-1 positive result all anımals in the herd were blood tested. The owners were also asked to give information of other possible contacts between the herd and other herds or, if any, contact with known seropositive herds. All positive herds were categorised as dairy herds or non-dairy herds defined as herds with no milk production. The number of infected cattle in the herd was registered on the day of blood testing and the days between introduction of a purchased animal and the confirmation of a BHV-1 positive diagnosis was calculated. The data were used to consider if the herd type or the number of days between introduction and detection of a seropositive anımal had any impact on the within herd spread of virus.

\section{Demonstration of antibodies to $\mathrm{BHV}-1$}

A Blocking ELISA test was used for the detection of antibodies against BHV-1 in both serum and bulk tank milk samples. (Nylin \& Rønsholt (in preparation)), (Nylin et al. (in preparation)). All samples were tested undiluted in duplicate at the Cattle Health Laboratory. Seropositive or suspect positive results of blood samples were confirmed by the Danish Veterinary Institute for Virus Research.

\section{Virus isolation}

From herds with suspicion of acute outbreak of IBR nasal mucous were sampled by the veterinary practitioner and sent to the Danish Veteri- 
nary Institute for Virus Research. The virus was recovered using standard methods (Rønsholt et al. 1987).

\section{Restriction Fragment Pattern analysis (RFP)}

Virus DNA from positive samples were purified and digested using the endonucleases EcoRI, $\mathrm{Bgl} \mathrm{II,} \mathrm{HpaI} \mathrm{and} \mathrm{HindIII.} \mathrm{(Christensen} \mathrm{\&} \mathrm{Nor-}$ mann 1992). Virus isolates recovered from herds with clinical outbreaks in 1993, 1994 and 1995 together with an isolate representative of the Danish strains before 1990 were compared to available vaccine strains*) and field strains supplied from the Netherlands, Hungary, Bulgaria, Estonia and Germany.

\section{Clinical observations}

Clinical signs in herds with confirmed virus isolation in 1995 were recorded by interviewing the veterinary practitioner about the number of clinically affected animals and the severity of the clinical signs with special reference to the body temperature and respiratory affections.

On the basis of the observed clinical manifestation the veterinary practitioners were asked to categorise the signs into one of 3 groups: Mild - including only discharge from eyes and nose. Severe - including dyspnoe and fever. Very severe - having restricted respiration, dyspnoe and pulmonary oedema, resulting in death of the animal.

\section{Aggregation of data:}

The information from suspected and infected herds in 1995, which has previously been published in the IBR - evaluation report (Anon. 1995) was collected by the state veterinary officers and the laboratories involved and adminis-

*) Duphavac (Duphar), Nasamune (Beecham), Respacine-3 (Syntex), Tracharine (Smith-Klıne), Cybov (Cynanıd), Bayvac (Bayer) tered in a common data base in collaboration with the Committee for Control of Infectious Cattle Diseases and the State Veterinary Services. Information collected from the outbreaks in 1995 was in addition used as basis of a national evaluation of the Danish BHV-1 surveillance program.

\section{Results \\ Epidemiological findings}

The geographical distribution of IBR-positive herds in Denmark in 1991-1994 and 1995 are shown in Fig. 1a and 1b. Between January 1991 and May 1994, 22 herds became infected with BHV-1. All positive herds were located in the southern part of Jutland close to the German border. They were all detected by the surveillance programme either due to an acute outbreak, a BHV-1 antibody positive reaction in a bulk tank milk sample during the winter season from November to May, or by a BHV-1 positive reaction in a blood sample drawn at slaughter. Concerning the situation in 1991-1994, the BHV-1 infection in 13 of the 22 herds was believed to be a result of primary introductions of virus into the herds, because these herds did not have any direct animal contact with other herds prior to seroconversion. No human or other indirect contact between these herds and known infected herds were revealed. Additional 4 herds became infected as a result of confirmed introduction of cattle from an infected herd. For 2 herds no direct animal contact with infected herds could be demonstrated, but since situated in an area close to infected herds, either human or secondary aerogen transmission route could have occurred. For 3 herds other routes than direct contact with infected cattle could not be excluded. In 3 of these 22 herds, acute clinical outbreaks of IBR were registered. (Fig. 1a). In 1995 a special situation occurred with the detection of 61 herds housing seropositive cat- 


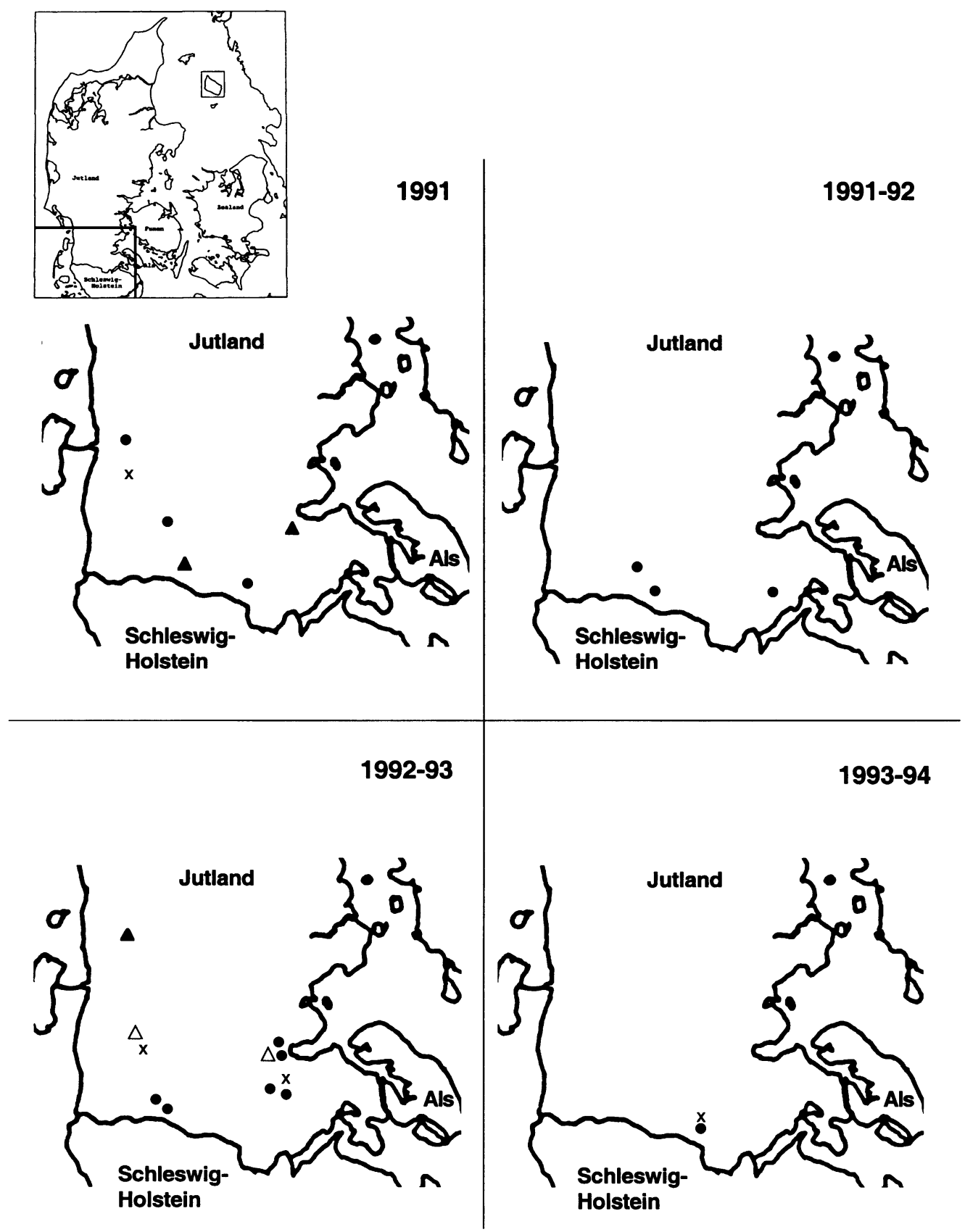

Figure 1a The geographical location of IBR positıve herds in Denmark in 1991-1994 Symbols are explained under Fig. 1 b. 

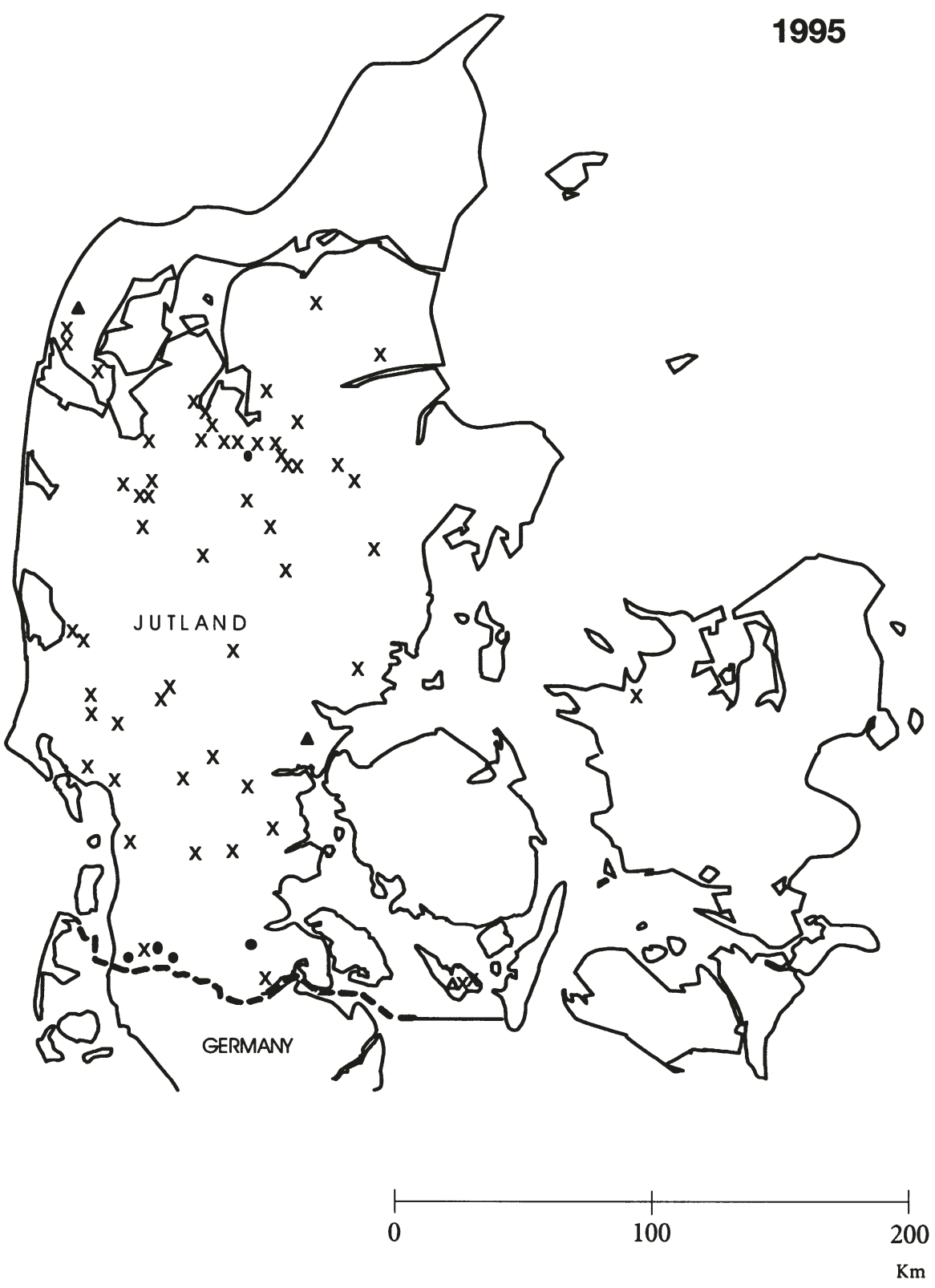

F1gure $1 \mathrm{~b}$ The geographical location of IBR positive herds in Denmark in 1995.

- Herds where no direct or indirect contact with other herds prior to seroconversion could be detected.

$\mathrm{X}$ Herds with a confirmed introduction of cattle from an infected herd

$\Delta$ Herds that might have had (but not confirmed) contact with infected herds.

$\triangle$ Herds infected due to spread of virus from a neighbouring herd. 
tle, 6 of these having a recorded clinical outbreak of IBR. The positive herds were situated in various parts of Denmark (F1g. 1b).

The 61 positive herds can be grouped according to their temporal recording and route of infection (Table 1).

In January-February 1995, 2 dairy herds were detected positive by the routine surveillance system on bulk tank milk. Most of the cattle in the 2 herds had seroconverted, indicating that virus had spread within the herd although no clinical signs were observed. The 2 herds, located in the southern part of Denmark close to the German border, had no confirmed direct or indirect contact with other herds.

In late spring of 1995 blood samples taken at slaughter from a herd in central Jutland were found BHV-1 seropositive. This herd had recived cattle from another herd (PT) located in central Jutland more than 200 kilometres north of the German border. Blood samples from the herd PT showed that all cattle were BHV-1 seropositive. The state veterinary officers' interview with the owners disclosed that cattle from PT had also been distributed to several other herds, which again had distributed cattle to further different herds. During a serological follow-up on these contacts, 51 BHV-1 seropositive herds were found. Herds that previously had sold cattle to the herd of PT were also bloodtested without detection of any serological positive anımals.

In 25 of these 51 herds, the seropositive animals were restricted to the introduced animals, while in 26 herds more than 3 seropositive reagents were found, indicating that some spread of virus had taken place. One of these herds was determined to be positive due to spread of virus from a neighbouring herd. The distribution of seropositive cattle in the infected herds is shown in Table 2.

The number of days from introduction of the infected animal to confirmation of the diagnosis varied from 10-62 days, with an average of 45 days for the 25 herds without virus spread, and from 9-145 days, with an average of 50 days for the 26 herds which experienced a spread of virus.

The number of dairy herds and non-dairy herds was evenly distributed in the 2 groups.

In autumn another 4 herds were found having BHV-1 seropositive cattle. The infections were related to confirmed direct anımal contact between the herds. Based on the follow up blood testing, it was concluded that the herd was infected before the main outbreak in 1995, but the route of introduction was unclear.

Again in November 1995 a non-dairy herd near the German border was found positive. Clinical signs of IBR were observed in December 1994, but no samples were at that time collected to confirm the suspicion.

In connection with the special survey for seropositive reagents in non-dairy herds in 1995, few cattle in 2 herds were found to present a suspect, low seropositive reaction against BHV-1.

Whether these reactions were due to a true infection with BHV-1 remain speculative, but the cattle were administratively considered BHV-1 positive and slaughtered.

\section{Restriction Fragment analysis}

Besides selected strains from outbreaks in herds near the German borders in 1993 and 1994, the HpaI generated patterns of obtained field strains from the 6 registered clinical outbreaks in 1995 connected to the infected herd (PT) in central Jutland are illustrated in Fig. 2a and $2 \mathrm{~b}$. The included BHV-1 Type I, Type III, and Type V are represented by K22 (IPV), $483 / 69$ and 540/89 (IBR) respectively.

Two different genotypes were identified among the isolates from the clinical outbreaks in 1995 after digestion with HpaI.

Isolates nos. 56/95, 71/95, 93/95 and 96/95 can 
Table 1. 61 Danısh BHV-1 positive herds recorded in 1995 stratıfied according to their temporal recording and the route of infection (see text for further explanation).

\begin{tabular}{|c|c|c|c|}
\hline Number of herds & Time of recordıng & Route of introduction of virus & Mode of recording \\
\hline 2 & January & Probably arrborne & Bulk tank milk samples \\
\hline $1(\mathrm{PT})$ & March & $\begin{array}{l}\text { Unknown but } \\
\text { probably import of } \\
\text { infectious cattle }\end{array}$ & $\begin{array}{l}\text { Interview followed by } \\
\text { individual serum samples }\end{array}$ \\
\hline 51 & March-July & $\begin{array}{l}\text { Contact with infected } \\
\text { cattle from PT }\end{array}$ & $\begin{array}{l}\text { Sample drawn at slaughter } \\
\text { Interview followed by } \\
\text { individual serum samples }\end{array}$ \\
\hline 4 & September & Unknown & $\begin{array}{l}\text { Interview followed by } \\
\text { individual serum samples }\end{array}$ \\
\hline 3 & September-November & Unknown & Individual serum samples \\
\hline
\end{tabular}

Table 2. Distribution of BHV-1 antibody positive cattle in 61 infected herds in 1995

\begin{tabular}{cc}
\hline Number of seropositive cattle & Number of herds \\
\hline $1-3$ & 33 \\
$4-10$ & 6 \\
$11-50$ & 10 \\
$>50$ & 12 \\
Total number of infected cattle was 1560 & Total number of herds was 61 \\
\hline
\end{tabular}

be grouped as belonging to the IBR genotype, (Type V) on the basis of the RFP patterns. The isolates from $1993(34 / 93)$ and 1994 (17/94, 20/94) show the same patterns and are as well grouped into BHV-1 Type V.

Isolates nos. $47 / 95$ and $92 / 95$, originatıng from 2 different herds, however, differ from other Danish isolates of the IBR type and the other 1995 isolates by the lack of fragments $3 a$ and 5 which grouped them as a BHV-1 subtype IV, being an evolutionary intermediate between Type III and Type V.

This differentiation was not obtained by digesting with the other enzymes HindIII, Bgl II and EcoRI (data not shown).

Combining the RFP analysis results of the virus strains from the 6 herds with clinical outbreaks and the information of known animal transfer between these herds, and the original infected herd of PT, indicates that the cattle from PT were infected by 2 different types of BHV-1. Type IV and type V (Fig. 3).

The collected field strains from different locations in Europe including available vaccine strains were digested with Hpa I. None of these strains expressed the same digesting pattern as the "new" Danish strain. (Data not shown).

\section{Clinical observations}

On the basis of the observation made by the veterinary practitioner, the severity of the 6 clinical outbreaks in 1995 was evaluated.

In at least 1 of the 2 herds affected, the "new" Danish strain seemed to be more virulent than the IBR genotype, which caused mild to severe clinical signs in 4 affected herds (Table 3). Unlike the classical moderate clinical findings seen with IBR, severe manifestations observed 

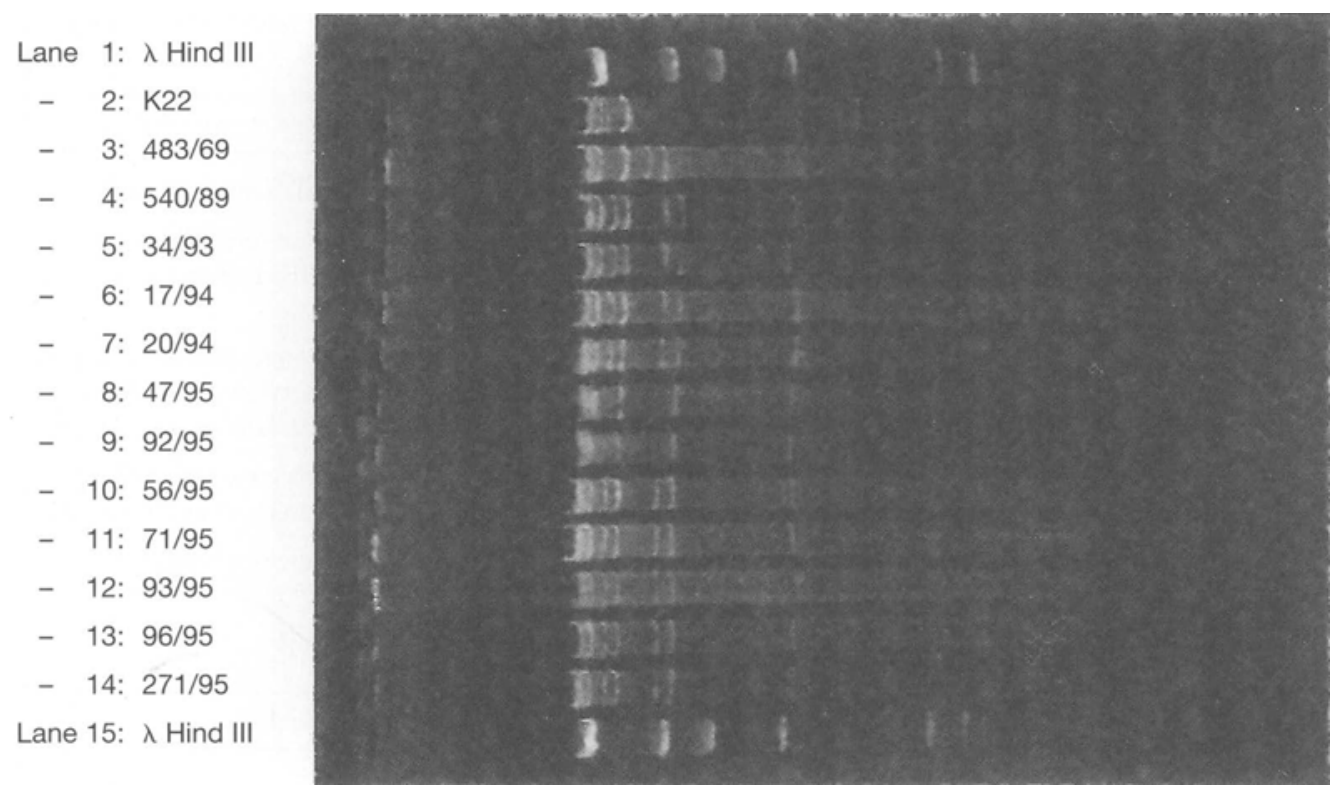

F1gure 2a. Hpa I restriction fragment patterns of Danish BHV-1 1solates

Lane 1 and 15: Molecular weight marker (Lambda HindIII);

Lane 2. IPV genotype (K22); BHV-1 Type I

Lane 3. Intermediate genotype"IPV/IBR" (DK 483/69); BHV-1 type III

Lane 4 IBR genotype (DK 540/89), BHV-1 type V

Lane 5 Isolate from outbreak of IBR in 1993;

Lane 6,7. Isolates from outbreaks of IBR in 1994,

Lane 8-14: Isolates from outbreaks of IBR in 1995

with the "new" strain were related to restriction of the respiration, pulmonary oedema, and death of some of the infected cattle, which ind1cate a virus strain of high virulence. The common pathological findings from these cattle were pulmonary oedema and crupoes tracheitis. (Figs. 4a and b).

\section{Discussion}

A programme for the systematic eradication of BHV-1 infections was carried out in Denmark between 1984 and 1991 without prophylactic vaccination, thus leaving the Danish cattle population highly susceptible to new introductions of BHV-1.
Despite the systematic eradication of BHV-1 and an effective control programme, recurrent infection of Danish cattle herds with BHV-1 occurred on few occasions during the period 1991-1995. Until 1995 reinfections were only detected near the southern border of Jutland, but in 1995 BHV-1 was isolated in a herd 200 kilometres north of this border area, and which apparently caused an epidemic outbreak of IBR.

Observations from every seropositive herd during 1991-1995 were registered, including serological surveillance of contact herds, molecular investigations (RFP-analysis) of isolated virus strains from clinical outbreaks and interviews with owners concerning movement of cattle or 
other possible contacts with infected or non-infected herds.

Based on recorded data from the seropositive herds during the period 1991-1995, 2 different routes of virus transmission into the Danish cattle population seem to be possible. One being a sporadic, local introduction of virus near the German-Danish border due to accidental contact with infected German cattle, or maybe due to an aerogen transport of BHV-1 from infected herds south of the Danish border. Circumstances which may explain the detection of 13 primary infected herds from 1991 to 1994,2 herds in January 1995 and one herd recorded in November 1995 . Another possibility of the introduction of BHV-1 could be an unauthorised import of BHV-1 infected cattle despite the national regulations. A situation that might explain the infection in the herd in the center of Jutland, where the intensive survey of all contact herds did not discover any other source of infection. The interesting finding of a new BHV-1 strain, not earlier detected in connection with IBR outbreaks in Danish cattle herds, supports this theory.

The hypothesis of an aerogen transmission of BHV-1 into Danish cattle herds has never been confirmed, although meteorological data of temperature, humidity and wind directions during the winter time supports this possibility (Nylin et al. 1995). The temperature and humidity in Denmark during the winter months limit the reduction of live virus numbers in aerosols (Schoenbaum et al.1990) and the current wind direction will enable transport of virus particles from infected herds south of the Danish border. Moreover, the border area represents a region with an intensive cattle production, which combined with a constant net flow of wind from south to north increases the risk of an airborne introduction of BHV-1 into Danish cattle herds.

Description of airborn transmission of infec-

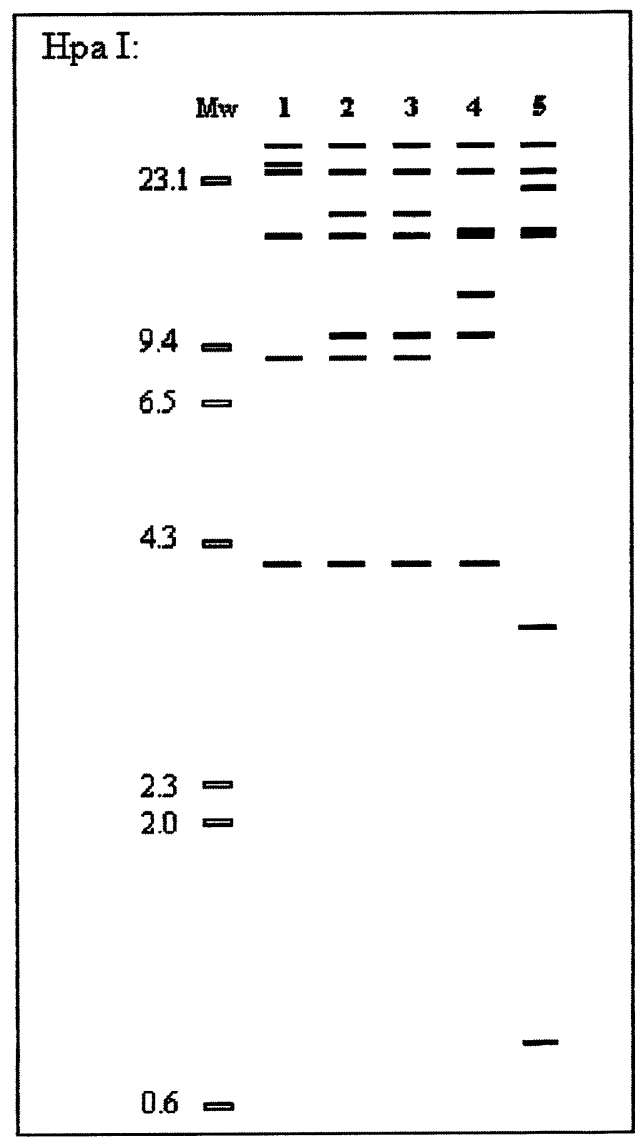

Figure 2b "Fingerprints" of Hpa I digested virus 1solates presented in Fig. 2a.

Mw: Molecular weight marker (Lambda HindIII);

Lane 1. Representative of isolates from 47/95 and 92/95 ("new strain"); BHV-1 type IV

Lane 2. Representative of other Danısh BHV-1 isolates from 1993-95; BHV-1 Type V

Lane 3: Prototype of typical IBR-like genotype (DK 540/89); BHV-1 Type V

Lane 4: Intermediate "IPV/IBR" genotype (483/69); BHV-1 Type III

Lane 5: IPV genotype (K 22). BHV-1 Type I

tious agents is limited, but studies of introduction of Suid herpes virus - 1 into Danish pig herds have lead to description of a possible aerogen transmission of Herpes-virus over 


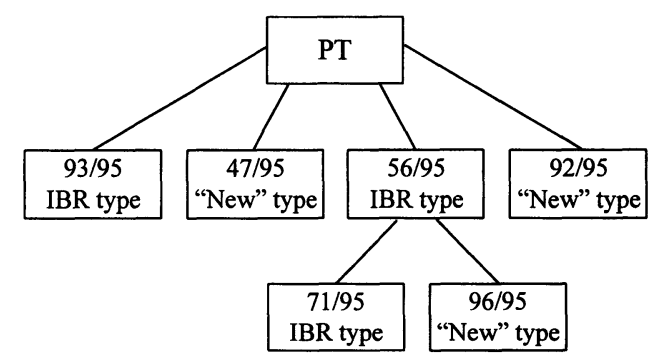

Figure 3: Combination of the RPF analysis results of the virus strains from the 6 herds with clinical outbreaks and the information of known anımal transfer between these herds and the original infected herd. The herd of PT has housed cattle infected with 2 different BHV-1 strains

Table 3. Summarised results of the RFP-analysis and the clinical observations of 6 herds with confirmed virus isolation.

\begin{tabular}{ccc}
\hline Journal no & BHV-1 strain & Clinical symptoms \\
\hline $47 / 95$ & "New" strain & Very severe \\
$56 / 95$ & IBR genotype & Mild \\
$71 / 96$ & IBR genotype & Severe \\
$92 / 95$ & "New" strain & Severe \\
$93 / 95$ & IBR genotype & Severe \\
$96 / 95$ & IBR genotype & Mild \\
\hline
\end{tabular}

short distances between farms (Bitsch \& Andersen 1982, Bitsch 1984 ), and transportation over the German-Danish border causing Aujeszky disease in Danish pig herds (Christensen et al. 1993). Only Foot and Mouth disease virus is well-known for its ability to be spread by air over long distances (Gloster et al. 1982).

Besides seropositive cattle herds, other ruminants like sheep and deer might be possible reservoirs for BHV-1 infection and thus be infectious to cattle. However, it its concluded that neither sheep experimentally infected with BHV-1 (J.J. Hage et al. 1997), nor Reed deer (Cervus elaphus) (Rønsholt et al. 1987) do easily transmit the infection, although they are housed in close contact with cattle.
Studies of transmission of BHV-1 virus within and between cattle herds are very limited. However, J. J. Hage (1997) recorded detailed data of introduction of BHV-1 virus into a population of 50 herds consisting of 3300 cattle situated on an isolated island. Four major outbreaks were recorded during the observational period, 3 of which were initiated by introducing seropositive animals to susceptible farms, and one probably being a reactivation and subsequent reexcretion of BHV-1. One of these outbreaks led to 3 secondary outbreaks in other herds, where direct contact between cattle, human transmission of virus, or an aerogen transport of virus between herds were the most likely reasons for introduction of virus.

In the situation described here, however, the transmission of infection was primarily a result of direct transfer of seropositive animals between herds, while human or aerogen transmission of virus could not completely be ruled out. From 1991 to 1994,4 herds were secondary by infected as a result of direct cattle contacts between herds, whereas in 1995 an extensive trade pattern involved a quick transfer of infected cattle to as many as $50 \mathrm{BHV}-1$ seronegative herds.

Besides the introduction of acutely infected, virus excreting cattle, transfer of seropositive latently infected cattle leading to reactivation of virus is one of the most common ways of introducing BHV-1 into susceptible herds. Stress due to transport and introduction to a new environment is some of the classical conditions, responsible for this reactivation of latent virus infection. (Pastoret \& Thirey 1985, Thirey et al. 1987, Kaashoek et al. 1996).

In the situation from 1995 a spontaneous spread of virus occurred in half of the seronegative herds after a seropositive animal was introduced. Once a seropositive animal had been introduced to a susceptible herd, the risk of within herd spread of virus was expected to be 

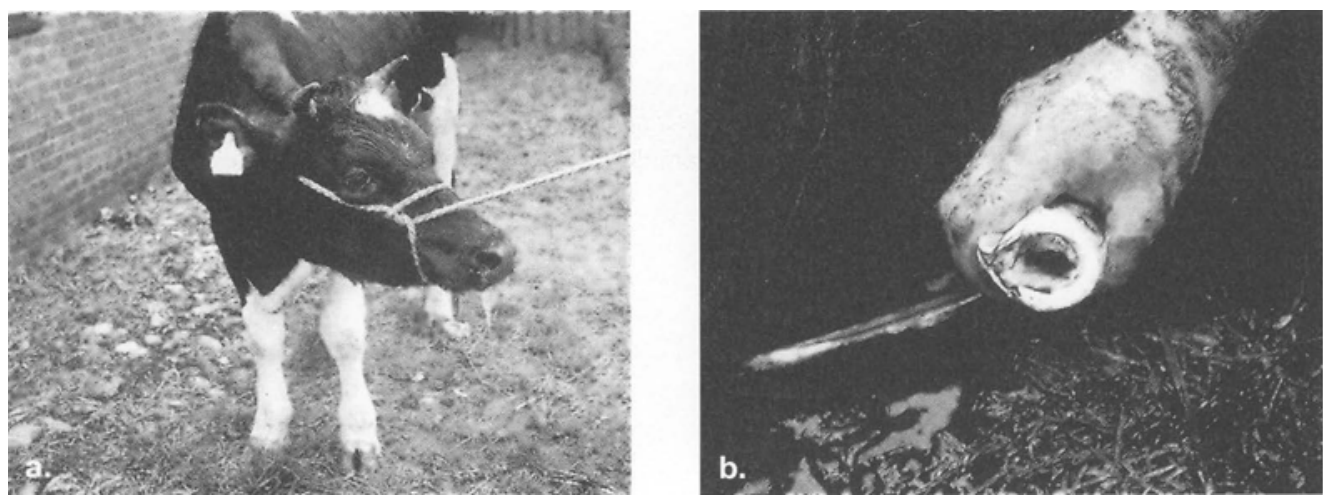

Figure 4. Cow with severe clinical signs of IBR.

a The head and neck are stretched out to compensate for the restricted respiration and pulmonary oedema.

b Section of the trachea from the cow in Fig. 4a. A $5 \mathrm{~mm}$ croupous membrane is present along the mucosa.

related to differences in herd type, as the dairy and non-dairy herds represent different types of management- and housing systems. There was a tendency to a more frequent with-in herd spread of virus in dairy herds than in non-dairy herds. However this difference was not statistically significant.

The time used for survey, reflecting the number of days from introduction of the infected animal to confirmation of infection by blood testing was on average 45-50 days. Within this period, half of the 50 herds had experienced a spread of virus.

The result of RFP analysis on the 6 available BHV-1 1solates from the disease outbreaks in 1995 demonstrated 2 different types of BHV-1 causing IBR. BHV-1 Type V, which was similar to the isolates from previous outbreaks in Denmark and a "new" strain, BHV-1 Type IV, which had never been identified in Denmark before. The 2 different strains were isolated from cattle originating from the same herd. Whether this was due to circulation of 2 strains at the same time in the herd or because the infected cattle originated from different herds remain speculative .
The occurrence of different strains of BHV1 within the same herd has previously been reported. A heifer, which was in close contact with different herds before entering a new herd, initiated a clinical outbreak from which 3 different BHV-1 strains were isolated. (Hage 1997).

Although the number of isolates are very limited, according to the clinical signs observed by the veterinary practitioner, it appears as if the "new" Danish strain may lead to more severe clinical manifestations than seen with BHV-1 type V. A virulence which may be connected to the genomic pattern (Msolla et al. 1983, Edwards et al. 1991, Kaashoek et al. 1996).

Divergent strains of BHV-1, including vaccine strains, are circulating in the European cattle population and vaccine strains may also become established in herds and cause clinical outbreaks. (Misra et al. 1983, Gregersen et al. 1985, Whetstone et al. 1986, Baker et al. 1989, Edwards et al. 1990). An observation, which was also confirmed by us, through the result of an RFP analysis performed on Dutch field strains. (Data not shown).

In an attempt to elucidate the geographical ori- 
gin of the new Danish BHV-1 isolate, the collected field and vaccine strains were analysed together with the "new" isolate. Using Hpa I as the restriction enzyme in the RFP, which is often used to demonstrate differences in BHV-1 strains, it was not possible to identify similarity between the new Danish isolate and field or vaccine strain.

The genotype of this new Danish strain, stated as type IV, may in the evolutionary systematisation of BHV-1 be placed between the intermediate Type III and the IBR-type, Type V. (Christensen et al. 1996) and it is postulated to be a representative of circulating but not previously discovered BHV-1 strain in the European cattle population.

From this study of recorded data of new infected herds it can be concluded that BHV-1 was reintroduced into the Danish cattle population during the period 1991-1995 and it is evident that different strains of BHV-1 were brought into the cattle herds during 1995.

Although an intensive follow-up on every $\mathrm{BHV}-1$ positive herd were performed, through a close collaboration between different authorities, the route of introduction of BHV-1 to Danish cattle herds still remains speculative.

Concerning the surveillance program for detection of antibodies to BHV-1 in Danish cattle herds it was concluded in the IBR evaluation report of the 1995 outbreaks, (Anon. 1995) that the performed monitoring of dairy herds on bulk tank milk samples are sufficient, but bloodsamples drawn at slaughter, may be insufficient due to lack of correct identification of the herd of origin.

\section{Acknowledgements}

The technical assistance of Preben Norman is greatly appreciated. The authors thank Bente B. Pedersen and Heidı Jørgensen for their help with the manuscript We also thank Jens Frederık Agger, Department of Animal Science and Anımal Health, The Royal Veterinary and Agricultural University, Fre- deriksberg, Denmark for his valuable discussions when preparing the manuscript.

We are grateful to Dr Peter Franken, Gezondheldsdienst voor dieren 1 Oost-nederland, Jan Brınkhof, Gezondheidsdienst voor Dieren en Midden Nederland and Dr. Johannes A Kramps, Lelystad for supplying the BHV-1 isolates from the Netherlands

\section{References}

Anonymous IBR evaluerıngs rapport 1995. Overvågnıngsudvalget for smitsomme kvægsygdomme og Veterinærdirektoratet. (IBR evaluation report 1995 The Committee for Control of Infections Cattle Disease and State Veterınary Services).

Baker J, Rust $S$, Walker $R$ Transmission of a vaccine strain of infectious bovine rhinotracheitis virus from intranasally vaccinated steers commingled with nonvaccinated steers Am. J. Vet Res. 1989, 50, 814-816

Bitsch V Aujeszky's disease genital diseases of cattle London recommendations Zoo-sanitary situation 11th Conference of the O.I.E-Regional Commision for Europe. Vienna, 25 -28. September 1984 .

Bitsch V, Andersen JB On the epidemiology of Aujeszky's disease in Denmark and the possibilities of its control. ECSC, EEC, EAEC, Brussels-Luxembourg, 1982. ISBN 90-247-2638-7.

Christensen LS, Normann $P$ A rapid method for purification of herpesvirus DNA. J Virol Methods 1992, 37, 99-102

Christensen LS, Mortensen S, Bøtner A, Strandbygaard BS, Rønsholt L, Henrıksen CA, Andersen $J B$ Further evidence of long distance airborne transmission of Aujeszky's disease (pseudorabies) virus Vet Rec 1993, 132, 317-321.

Christensen LS, Madsen KG, Nylin B, Rønsholt L A contribution to the systematization of bovine herpesvirus 1 based on genomic mapping by restriction fragment pattern analysis. Virus Research, 1996, 46, 177-182.

Edwards $S$, White $H$, Nixon $P$ A study of the predominant genotypes of bovid herpesvirus found in the U.K. Vet Microbiology 1990, 22, 213-223

Edwards $S$, Mewman RH, White $H$ The virulence of Britısh isolates of bovid herpesvirus 1 in relation to viral genotype. Br.vet. J. (1991), 147, 216.

Engels $M$, Streck F, Wyler $R$ Comparisation of the genome of Infectious Bovine Rhinotracheitis and Infectious Pustular Vulvovaginitis Virus Strains 
by Restriction Endonuclease Analysis. Arch. virol. 1981, 67, 169-174.

Gloster J, Sellers RF, Donaldson AI - Long distance transport of foot-and-mouth disease virus over the sea. Vet. Rec 1982, 110, 47-52.

Gregersen JP, Wagner K: Persistent infection of the genital tract and excretion of the vaccine strain after live virus immunization with bovine herpesvirus-1 (IBR/IPV virus). Zbl. Vet.-Med [B] 1985, 32, 354-360.

Hage $J J$. Epidemiology of bovine herpesvirus 1 infections, 1997. Elınkwijk BV, Utrecht. (Thesis).

Kaashoek MJ, Straver PH, Van Roolj EMA, Van Oirschot JT. Virulence, 1mmunogenicity and reactivation of seven bovine herpesvirus 1.1 strains: clinical and virological aspects. Vet. Rec. 1996, 139, 416-421.

Misra V, Babiuck LA, Darcel C le $Q$ Analysis of bovine herpesvirus type 1 isolates by restriction endonuclease fingerprintıng Arch Virol, 1983, 76, 341-354.

Msolla PM, Wiseman A, Allan, Selman IE. A comparison of the virulence of three strains of infectious bovine rhinotracheitis virus Vet Microbiol. 1983, 8, 129-134.

Nylin B, Mortensen S, Henriksen CA, Rønsholt L, Christensen $L S \cdot$ Ep1demiologiske og meteorologiske forhold omkring tilbagevendende nysmitte af kvægbesætnınger 1 Sønderjylland med IBRvirus. (Epidemiological and meteorological aspects of reintroduction of IBR-virus into cattle herds in South-Jutland). Dansk Veterinær Tidsskrift 1995, 78, 16, 15/8.

Nylin B, Rønsholt $L$ An evaluation of the blocking ELISA system practised in the Danısh National BHV-I eradication program, 1984-1991 (In prep.)

Nylin B, Strøger U, Rønsholt Evaluation of a BHV-1 antıbody ELISA on bulk-tank milk samples from Danısh dairy herds. (In prep.)

Pastoret PP, Thiry E Diagnosis and prophylaxis of infectious Bovine Rhinotracheitis' The role of virus latency Comp Immun. Microbiol. infect. Dis. 1985, 8, 35-42.

Rønsholt L, Christensen LS, Bitsch V Latent herpesvirus infection in red deer Acta vet. scand. $1987,28,23-31$
Schoenbaum MA, Zimmerman JJ, Beran GW, Murphy $D P$ Survival of pseudorabies virus in aerosol. Am J. Vet. Res. 1990, 51, 331-333.

Thiry E, Salik J, Bublot M, Pastoret PP: Reactıvation of infectious bovine rhinotracheitis virus by transport. Comp. Immunol. Microbiol. Infect. Dis. 1987 10, 59-63.

Whetstone $C A$, Wheeler $B S$, Reed $D E$. Investigation of possible vaccine-induced epizootics of infectious bovine rhinotracheitis, using restriction endonuclease analysis of viral DNA. Am. J. Vet. Res. 1986, 47, 1789-1795.

\section{Sammendrag}

Re-introduktion af bovint herpes virus 1 l danske kvagbesatninger i perioden 1991-1995

På trods af en systematısk bekæmpelse af bovint herpes virus 1 (BHV-1) 1 årene 1984 tıl 1991, kom der nye udbrud til 1 de efterfølgende år. I perioden januar 1991 til november 1994 blev der opdaget 22 ny-smittede besætnınger, der alle lå tæt ved den dansk-tyske grænse I 1995 blev 61 besætninger fundet som nyinficerede. Disse var på nær de 2, der lå tæt på grænsen, fordelt over landet. Forsøget på at finde kılden tıl de mange udbrud omfattede opfølgning på handelsveje og andre kontakter mellem besætnıngerne, samt molekylær-bılologiske metoder på det 1solerede virus fra de observerede klınıske udbrud.

De isolerede stammer fra udbruddene før 1995 havde alle samme RPF-mønster, mens der fra 2 af udbruddene 11995 blev ident1ficeret en BHV-1 type, der 1kke tıdligere var 1soleret fra danske udbrud eller fra udbrud andre steder 1 Europa

Ved en gennemgang af de registrerede tilfælde af nysmitte med BHV-1, tegner der sig to muligheder for smitteındførsel tıl danske besætnınger En lokal indførsel tıl besætninger 1 det grænsenære område 1 Sønderjylland, formentlig enten på grund af kontakt med tyske besætnınger eller på grund af en luftbåren transport af virus, eller en indførsel af et eller flere infektıøse dyr fra udlandet på trods af gældende nationale restriktioner I hvor stort omfang infektionen udbredes t1l andre besætnınger afhænger blandt andet af de handelskontakter, der er mellem besætningerne. I 1995 blev infektionen udbredt t1 50 besætnınger, som følge af kontakt med blot én smittet besætnıng

(Recelved October 15, 1997, accepted July 3, 1998)

Reprints may be obtaıned from· B Nylın, Cattle Health Laboratory, Danısh Dairy Board, Ladelundsvej 85 A, DK-6650 Brørup, Denmark. E-mall: bny@mejerı dk, tel: +45 76600 613, fax +45 76600601 
